\title{
Monetary Policy Coordination and the Role of Central Banks
}




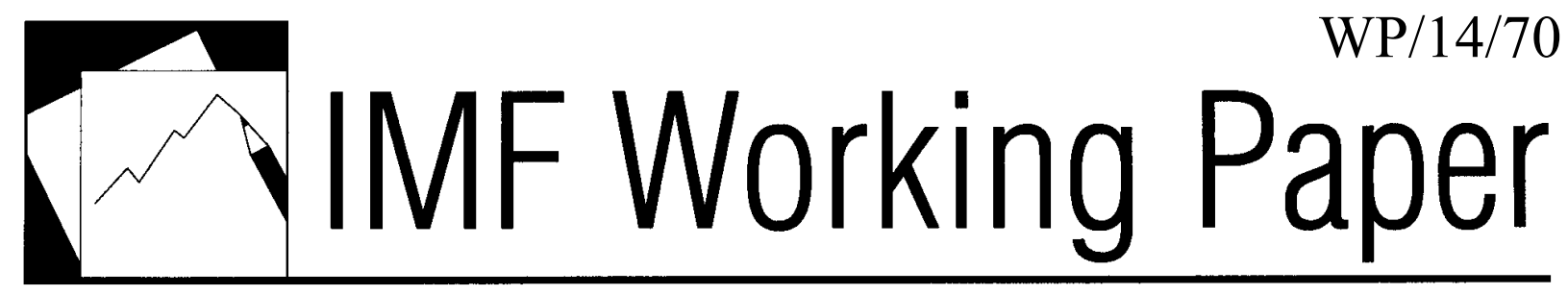

Monetary Policy Coordination and the Role of Central Banks

Rakesh Mohan and Muneesh Kapur 


\title{
IMF Working Paper
}

Office of the Executive Director

\section{Monetary Policy Coordination and the Role of Central Banks ${ }^{1}$ \\ Prepared by Rakesh Mohan and Muneesh Kapur}

April 2014

\section{This Working Paper should not be reported as representing the views of the IMF.} The views expressed in this Working Paper are those of the author(s) and do not necessarily represent those of the IMF or IMF policy. Working Papers describe research in progress by the author(s) and are published to elicit comments and to further debate.

\begin{abstract}
The unconventional monetary policies (UMPs) pursued by the advanced economies (AEs) have posed macroeconomic challenges for the emerging market economies (EMEs) through volatile capital flows and exchange rates. AE central banks need to acknowledge and appreciate the spillovers resulting from such UMPs. Central banks of the AEs, who have set up standing mutual swap facilities, should explore similar arrangements with other significant EMEs with appropriate risk mitigation measures. These initiatives could do much to actually curb volatility in global financial markets and hence in capital flows to EMEs, thus obviating the need for defensive policy actions on the part of EMEs.
\end{abstract}

JEL Classification Numbers: E52, E58, E61, F33, F42

Keywords: Capital flows, central banks, coordination, emerging markets, unconventional monetary policy, spillovers

Author’s E-Mail Address:rmohan@imf.org, mkapur@imf.org

\footnotetext{
${ }^{1}$ Paper prepared for the conference "The G-20 at Five" held on November 14-15, 2013 in Canberra, Australia. The views expressed in the paper are those of the authors and not necessarily those of the institutions to which they belong. Comments from Olivier Blanchard, Colin Bradford and Siddharth Tiwari on earlier drafts are gratefully acknowledged; the usual disclaimer applies.
} 


\section{Contents}

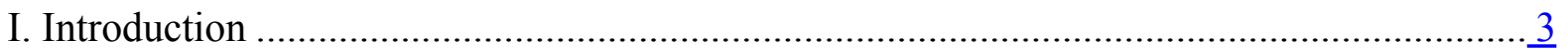

II. Monetary Policy in the Post-Crisis Period: Continued Domestic Orientation and Large

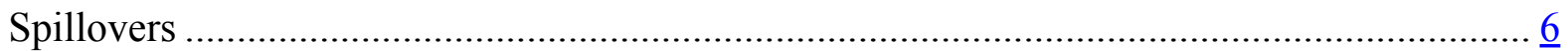

Conventional Monetary Actions: Uncoordinated ……………………………………... $\underline{6}$

Liquidity Swap Facilities: Coordinated ............................................................... 7

Unconventional Monetary Policy: Uncoordinated …………………………………...... 9

III. Monetary Policy in the Advanced Economies: Spillovers to the EMEs .......................... 11

Volatile Capital Flows and Exchange Rates: Risks to Financial Stability ……………... 11

Impact of the UMP on EMEs............................................................................ 17

IV. International Monetary Coordination: Scope and Feasibility …………………………... 20

V. Management of Spillovers by the EMEs .................................................................. 23

Capital Account Management................................................................................. 23

Regional Financing Arrangements .................................................................. 25

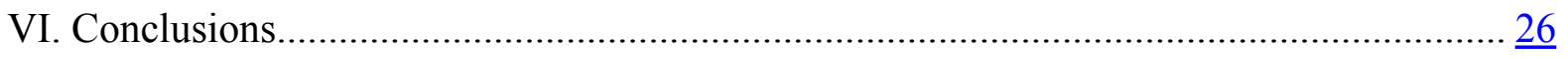

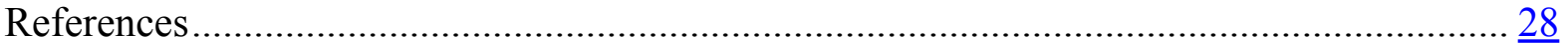

Figure 1: US Dollar Liquidity Swaps by the Federal Reserve............................................. $\underline{8}$

Figure 2: Central Bank Assets …………………………………………………….... $\frac{10}{12}$

Figure 3: Private Capital Flows to Emerging and Developing Economies ............................ $\frac{12}{12}$

Figure 4: Monthly Equity and Bond Flows to EMEs ………………….......................... $\frac{13}{16}$

Figure 5: Exchange Rate Movements .......................................................................... $\frac{16}{16}$

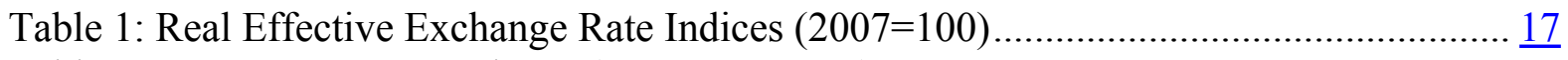

Table 2: Current Account Balance (Percent to GDP) ............................................................ 18 


\section{INTRODUCTION}

Since the onset of the North Atlantic financial crisis (NAFC) in 2008, central banks in the US and the other major advanced economies have pursued highly accommodative monetary policy, including through unconventional policy actions. Accordingly, policy rates have been near zero in these economies for almost five years, and both short-term and longterm interest rates have touched historic lows. These low interest rates encouraged the search for yield and consequently, large amounts of capital flowed out from these reserve-currency economies to the still relatively fast-growing emerging market economies (EMEs), complicating their macroeconomic management. Capital flows to the EMEs are well-known for their volatility. This volatility was again in evidence during May-August 2013, when the US Federal Reserve first hinted at possible tapering from its unconventional monetary policy (UMP) and again in January 2014 after the actual tapering began. The mere announcement of tapering in May 2013 led to large capital outflows from the major EMEs, resulting in sudden and large currency depreciations and ignited fears of the 1980s and 1990s type crises in these EMEs. However, stronger macroeconomic and financial policies pursued and the buffers built by these economies over the past decade have helped them to avoid a full-blown financial crisis this time around. Nonetheless, the tapering episode has hurt their near-term growth prospects significantly, while also illustrating the potential underlying vulnerabilities in the international monetary system.

The developments since 2008 have put a spotlight on the key role that monetary policy in the reserve-currency countries has on the rest of the global economy. Given these spillovers, there is a renewed debate on the merits of co-ordination of monetary policy among the major central banks. The conventional wisdom is that there are no benefits from international coordination of monetary policies: in this view, the global economy is best served by central banks focusing on their respective domestic inflation and output objectives. This view is analogous to the conventional wisdom with regard to domestic financial regulation that was pre-dominant before the NAFC: here, the view was that effective microprudential regulation of individual institutions would ensure systemic stability of the overall financial system, but this view stands weakened post-NAFC. Accordingly, the focus of financial regulation is now moving towards both micro- and macro-prudential regulation so that financial stability can be fostered; serious efforts are in process to foster international cooperation on key regulatory issues through the Financial Stability Board (FSB). Similarly, the pre-NAFC dominant orthodoxy was that the central banks should be one-objective oneinstrument institutions (focus on price stability and with short-term interest as the only instrument) and financial regulation was best kept outside the central banks. This orthodoxy also stands challenged by the 2008 crisis and there is now a greater recognition of synergies between the central banks being entrusted with monetary policy as well as financial regulation. The central banks' institutional set-up is being re-designed accordingly (for example, the Bank of England, the European Central Bank and the US Federal Reserve).

The banking sector regulatory architecture has been characterized by international cooperation for a number of decades now - the Basel I, II and III standards are the well- 
known outcomes of this approach (Caruana, 2012a). The NAFC provided an impetus to international economic and financial coordination, especially regulatory coordination and "unprecedented and concerted" fiscal expansion. Against the background of deteriorating economic conditions worldwide in the aftermath of the Lehman collapse in October 2008, the G-20 Leaders at their Washington Summit (November 15, 2008) agreed that "a broader policy response is needed, based on closer macroeconomic cooperation, to restore growth, avoid negative spillovers and support emerging market economies and developing countries." At the direction of the Leaders, the G-20 constituted four working groups and these were tasked with the objectives of: Enhancing Sound Regulation and Strengthening Transparency; Reinforcing International Cooperation and Promoting Integrity in Financial Markets; Reform of the IMF; and, Reform of the World Bank and other Multilateral Development Banks.

The G-20 Leaders initiatives led to a significant strengthening of financial sector regulations and the regulatory architecture, including the establishment of the Financial Stability Board (FSB) in April 2009. The FSB was a response to the November 2008 call from the Leaders of the G20 for a larger membership of the erstwhile Financial Stability Forum. The FSB coordinates the work of national financial authorities and international standard setting bodies in order to develop and promote the implementation of effective regulatory, supervisory and other financial sector policies. At their Pittsburgh Summit (September 2009), the G-20 Leaders pledged to work together to ensure a lasting recovery and strong and sustainable growth over the medium term. To meet this goal, they launched the "Framework for Strong, Sustainable, and Balanced Growth".

The G-20 initiatives also led to a noteworthy increase in the resources and lending capacity of the IMF in 2009 and again in 2012, which was a critical step in restoring global financial stability. At the G-20 London Summit (April 2009), the Leaders agreed to treble the resources available to the IMF to US\$ 750 billion, to support a new SDR allocation of US\$ 250 billion, at least US\$ 100 billion of additional lending capacity for the multilateral development banks, and to ensure US\$ 250 billion of support for trade finance. The G-20 initiatives led to an additional US\$ 450 billion of resources for the IMF through bilateral borrowings in 2012. However, the delay in ratification of the 2010 quota and governance reforms has veered the Fund away from being a quota-based institution to depend increasingly upon borrowed resources; as a result, quota and voting shares of many dynamic EMEs are lower than their relative economic weights in the global economy, raising serious issues of governance and potential implications for effective Fund surveillance and advice. Overall, there have been welcome G-20 led initiatives at improving international economic and financial coordination since the onset of the NAFC and these have played a critical role in providing some stability to the global economy, while avoiding a repeat of the 1930s Great Depression.

As far as international monetary policy coordination is concerned, the traditional view of domestically-oriented monetary policy is still seen as the optimal arrangement, although there are calls for a re-assessment (Eichengreen and others, 2011). In Saint Petersburg in September 2013, the G-20 Leaders echoed the conventional view: "Monetary policy will 
continue to be directed towards domestic price stability and supporting the economic recovery according to the respective mandates of central banks", although being "mindful of the risks and unintended negative side effects of extended periods of monetary easing. We recognize that strengthened and sustained growth will be accompanied by an eventual transition toward the normalization of monetary policies. Our central banks have committed that future changes to monetary policy settings will continue to be carefully calibrated and clearly communicated" (G-20 Leaders Declaration, Saint Petersburg Summit, September 5-6, 2013).

It is, however, not the case that there has been no coordination at all. In the aftermath of the NAFC, the activation of swap lines by the US Federal Reserve with central banks in major advanced economies and a few select emerging markets is an example of some coordination, but this coordination appears to have been motivated by the likely adverse impact of the sudden drying up of liquidity in these advanced economies on themselves. Thus, this coordination does not appear to have been motivated by the likely impact of their monetary policies on the EMEs, an issue that is the focus of this paper. Similarly, the Plaza and the Louvre Accords of 1985 and 1987 are well-known illustrations of international monetary coordination on the currency front, wherein the major industrial countries agreed to depreciate the US dollar by engaging in coordinated interventions in the foreign exchange markets (Frieden and Broz, 2013).

Although there is no regular coordination among the major central banks on monetary policy actions, a great deal of discussion does occur among leading central banks at various international fora. The major forum for such discussions is provided by the BIS through bimonthly meetings of central bank governors, supplemented by periodic meetings of deputy governors. G-20 and G-7 are the other major international fora. Various conferences held by major central banks - for instance, the annual Jackson Hole conference - provide another opportunity for central bankers to exchange views, but these conferences focus mostly on analytical issues for monetary and other economic policies. Arguably, monetary policymakers share a more thoroughly elaborated intellectual framework than their counterparts in financial regulation - well illustrated by the dominant consensus in favor of inflation targeting monetary policy frameworks in the pre-NAFC period, but then such a consensus has its pitfalls as revealed by the NAFC.

The issue of international monetary policy coordination or, rather lack of it, attracted a lot of attention and debate in early 2014 following the renewed turmoil in some emerging markets. The subsequent remarks by Rajan (2014a) that international monetary policy cooperation has broken down have been widely debated. He argues that "the US should worry about the effects of its policies on the rest of the world........we would like to live in a world where countries take into account the effect of their policies on other countries and do what is right, broadly, rather than what is just right given the circumstances of that country". This view gets some support from Buiter (2014) and Eichengreen (2014) who also argue that the US Fed needs to acknowledge that its policies may have significant spillovers on the other economies. Eichengreen (2014) suggests that the Fed should negotiate permanent dollar swap facilities with major EMEs, as it has with other advanced economies. 
Ranged against such views are others (e.g. Prasad, 2014) who argue that the root of the volatility in EMEs is not the US Fed's monetary policy but is much more a failure of their own domestic policies. Moreover, it is felt that international coordination, though logical, is unlikely to work. The skeptics believe that faith in global economic policy coordination is misplaced and that it is naïve for EME governments to expect major financial centers to adjust their economic policies in response to economic conditions elsewhere (Rodrik, 2014). According to this view, the EMEs' vulnerability in mid-2013 is the outcome of their own misplaced conscious embrace of financial globalization: there was no domestic compulsion forcing the major EMEs to woo foreign capital as they did in recent years (Rodrik and Subramanian, 2014). If this view is taken to its logical conclusion, the EMEs should have protected themselves from the excess capital flows from advanced economies as a consequence of UMP. Rajan's appeal for international monetary coordination is to ward off such arguments that could lead to fragmentation of global financial markets.

Against this backdrop, this paper discusses the scope for international monetary policy coordination, although it has been commented that "International policy coordination is like the Loch Ness monster - much discussed, but rarely seen" (Blanchard, Ostry and Ghosh, 2013). The paper begins with a review of the monetary policies in the major advanced economies since 2007 and assesses the extent of coordination among the major central banks (Section II). Section III then moves to the spillovers of monetary policies in the advanced economies to the EMEs, and focuses on the key channels - capital flows and exchange rates - of these spillovers and the implications thereof for the EMEs. Section IV critically assesses the scope and feasibility for international monetary coordination, while Section V discusses options for the EMEs to manage the spillovers. Concluding observations are in Section VI.

\section{Monetary Policy in the Post-Crisis Period: Continued Domestic ORIENTATION AND LARGE SPILlOVERS}

\section{Conventional Monetary Actions: Uncoordinated}

With the onset of the sub-prime crisis in August 2007, the US Federal Reserve switched its monetary policy stance towards an easing mode beginning September 2007. The US Fed rapidly cut its policy rate from 5.25 percent in August 2007 to 2.0 percent by April 2008 and reached the zero bound by December 2008. It remains at that level five years later. The monetary response of the Bank of England $(\mathrm{BoE})$ and the Bank of Canada (BoC) broadly tracked the US Federal Reserve. The European Central Bank (ECB) initially paused until mid-2008, then tightened a little bit and went into an easing mode in October 2008 following the collapse of Lehman Brothers; the ECB reached its lowest rate of 0.25 percent in November 2013. Other central banks displayed a more varied two-way response.

Overall, since the summer of 2007, the conventional interest rate actions of the various central banks were in response to their respective domestic situations, but were heavily influenced by developments in the US. However, on one occasion (October 8, 2008) - the immediate aftermath of the Lehman collapse - there was a coordinated reduction of 25- 
50 basis points in the policy interest rates by the central banks of six advanced economies ${ }^{2}$ to ease "global monetary conditions" (Board of Governors of the Federal Reserve System, 2008a; Eichengreen, 2013b) ${ }^{3}$. The FOMC members welcomed the opportunity to coordinate this policy action with similar measures by other central banks:

"By showing that policymakers around the globe were working closely together, had a similar view of global economic conditions, and were willing to take strong actions to address those conditions, coordinated action could help to bolster consumer and business confidence and so yield greater economic benefits than unilateral action" (Board of Governors of the Federal Reserve System, 2008b).

Thus, in this instance, the US Fed is on record to accept that coordinated action could be better than unilateral action.

The G-20 meetings were relatively more forthright on the need for a coordinated fiscal stimulus, but less so in the case of monetary stimulus. This apparently divergent G-20 approach perhaps reflected the pre-NAFC consensus that monetary policy, and not fiscal policy, is better suited for macroeconomic stabilization. As documented above, almost all central banks had started monetary easing by October 2008 (with the US taking the lead and almost in the vicinity of the zero bound by that time). As regards fiscal policy, the pre-NAFC orthodoxy typically viewed fiscal multipliers as low, and hence limited gains were seen from fiscal policy in many quarters. And, since monetary policy actions had already been taken actions beginning October 2008, this might have also made fiscal authorities somewhat hesitant to loosen their fiscal policies.

\section{Liquidity Swap Facilities: Coordinated}

In contrast to the conventional monetary policy actions (policy interest rates), there has been a higher degree of coordination among the major central banks on the provision of liquidity through swap facilities, although the utilization of these facilities has been a oneway operation (from the US Federal Reserve to other select central banks). In the aftermath of the sub-prime crisis, concerns about credit risk and higher demand for liquidity placed extraordinary strains on the global market for inter-bank funding in US dollars. Accordingly, the Federal Reserve entered into US dollar liquidity lines, beginning December 2007, with the ECB and the Swiss National Bank (SNB). These facilities were extended to another 12

\footnotetext{
${ }^{2}$ Bank of Canada, Bank of England, European Central Bank, Federal Reserve, Sveriges Riksbank, and Swiss National Bank.

${ }^{3}$ An earlier occasion of coordinated interest cut and liquidity provision was by the G-7 in response to the 1987 stock market crash in the US (Ostry and Ghosh, 2013).
} 
central banks during September-October $2008^{4}$. These swap facilities have been renewed at times and, at present, these arrangements exist with five central banks ${ }^{5}$. The US Fed boosted the available liquidity under these swap lines from US \$ 67 billion in December 2007 to US $\$ 620$ billion in early October 2008; in view of deteriorating market conditions, the Fed further expanded the swap amounts in mid-October 2008 by removing the caps on its swap facilities with four major central banks (the ECB, the Bank of England (BoE), the SNB and the Bank of Japan). The amounts availed under the swaps peaked at US \$580 billion (over 25 percent of the Fed's total assets) in mid-December 2008 (Figure 1).

\section{Figure 1: US Dollar Liquidity Swaps by the Federal Reserve}

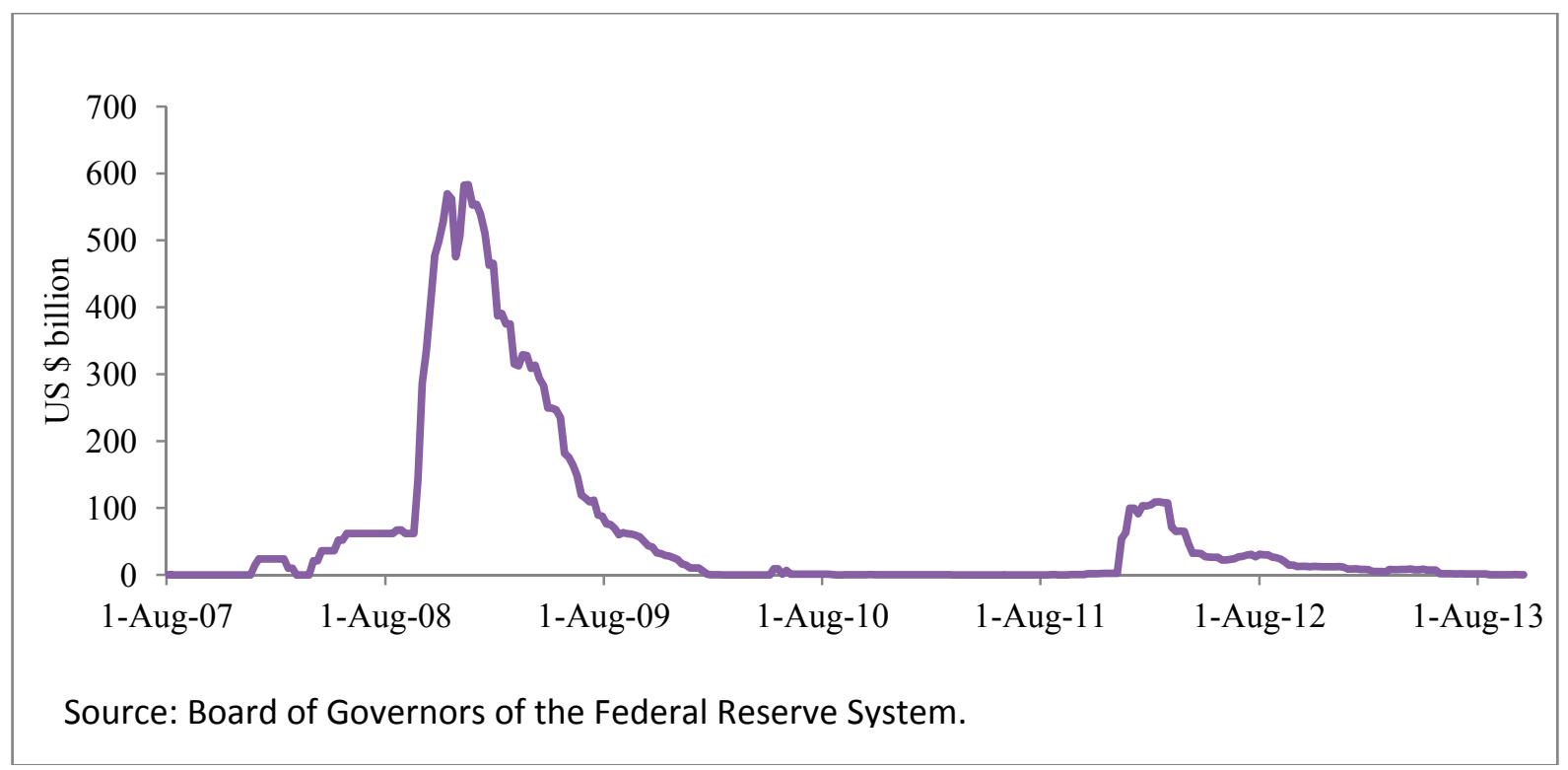

The US Fed also entered into foreign-currency liquidity swap lines in April 2009 with four major central banks ${ }^{6}$ and these were renewed in November 2011 (while also adding the Bank of Canada to this list). These lines, which mirrored the US dollar liquidity swap lines, were designed to provide the Federal Reserve with the capacity to offer liquidity to U.S. institutions in foreign currency. While the Federal Reserve did not draw on these foreigncurrency swap lines, its US dollar liquidity swap facilities were heavily used. In end-October 2013, these six central banks ${ }^{7}$ decided to convert their existing temporary bilateral liquidity

\footnotetext{
${ }^{4}$ These additional 12 central banks were: Reserve Bank of Australia, Banco Central do Brasil, Bank of Canada, Danmarks Nationalbank, Bank of England, Bank of Japan, Bank of Korea, Banco de Mexico, Reserve Bank of New Zealand, Norges Bank, Monetary Authority of Singapore, and Sveriges Riksbank.

${ }^{5}$ Bank of Canada, Bank of England, European Central Bank, Bank of Japan, and Swiss National Bank.

${ }^{6}$ Bank of England, European Central Bank, Bank of Japan, and Swiss National Bank.

${ }^{7}$ Bank of Canada, Bank of England, Bank of Japan, European Central Bank, Federal Reserve, and Swiss National Bank.
} 
swap arrangements to standing arrangements - that will remain in place until further notice on the grounds that the existing temporary swap arrangements have helped to ease strains in financial markets and mitigate their effects on economic conditions and the standing arrangements will continue to serve as a prudent liquidity backstop.

These swap facilities instituted since 2008 have a long history - in fact, they are at least a century old. Between the 1880s and 1920s, the Bank of England drew upon gold loans from the central banks of France and Germany to protect the gold standard in lieu of the option to raise interest rates which would have then had a negative impact on the real economy. In the post-World War II period, the US Fed negotiated a network of swap lines with eight foreign central banks during the 1960s, aggregating US \$ 2 billion. These swap lines were utilized by the UK, Canada and the US. The US Federal Reserve drew fully the US\$ 150 million swap line with the Bundesbank in the 1960s. In 1961, the advanced economies also negotiated the General Arrangements to Borrow (GAB), as a preventive tool, to enable countries to borrow larger amounts of their currencies through the IMF, partly necessitated by the restoration of current account convertibility and the potential need for more financing (Eichengreen, 2011 and 2013b). Like the GAB mechanism, the IMF has since 2009 used the New Arrangements to Borrow (NAB) and the Bilateral Borrowing arrangements to expand its resources, given the large financing needs in the post-2008 crisis scenario and the inability to increase its quotas in a timely manner. Overall, it can be argued that international monetary coordination is not as rare as sometimes implied.

\section{Unconventional Monetary Policy: Uncoordinated}

With the constraint of the zero bound on policy interest rates, central banks of the major advanced economies turned to unconventional monetary policies (UMP) to provide more monetary accommodation through quantitative easing $(\mathrm{QE}) /$ large scale asset purchase (LSAP) policies. These actions have been aimed at depressing the long-term interest rates in these economies in order to boost economic activity. As a result, the balance sheets of these central banks have expanded in a significant manner. Here again the response has been uncoordinated, with the US Federal Reserve taking the lead. In local currency terms, the US Fed and the Bank of England have almost quadrupled their respective balance sheets between end-2007 and September 2013. The Swiss National Bank (SNB) has also quadrupled its balance sheet in pursuit of its policy to peg the Swiss Franc to resist its appreciation. The balance sheets of the ECB and the BoJ have expanded relatively moderately - by around 55 and 87 percent, respectively. The ECB's balance sheet had by mid-2012 more than doubled over its end-2007 level, but it has been scaled back with the return of some normalcy in the financial markets. As proportion of their respective GDP levels, the balance sheets have also recorded notable increases between 2007 and 2012: nearly doubling for the ECB to 32 percent of GDP, and trebling (or more) for the BoE, the US Fed and the SNB (26 percent, 18 per cent, and 84 percent of their GDP, respectively (Figure 2). Overall, the combined balance sheets of the US Federal Reserve, the ECB, the BoE, the BoJ and the SNB have more than doubled since end-2007 to US \$ 10 trillion as of August 2013. 
Figure 2: Central Bank Assets

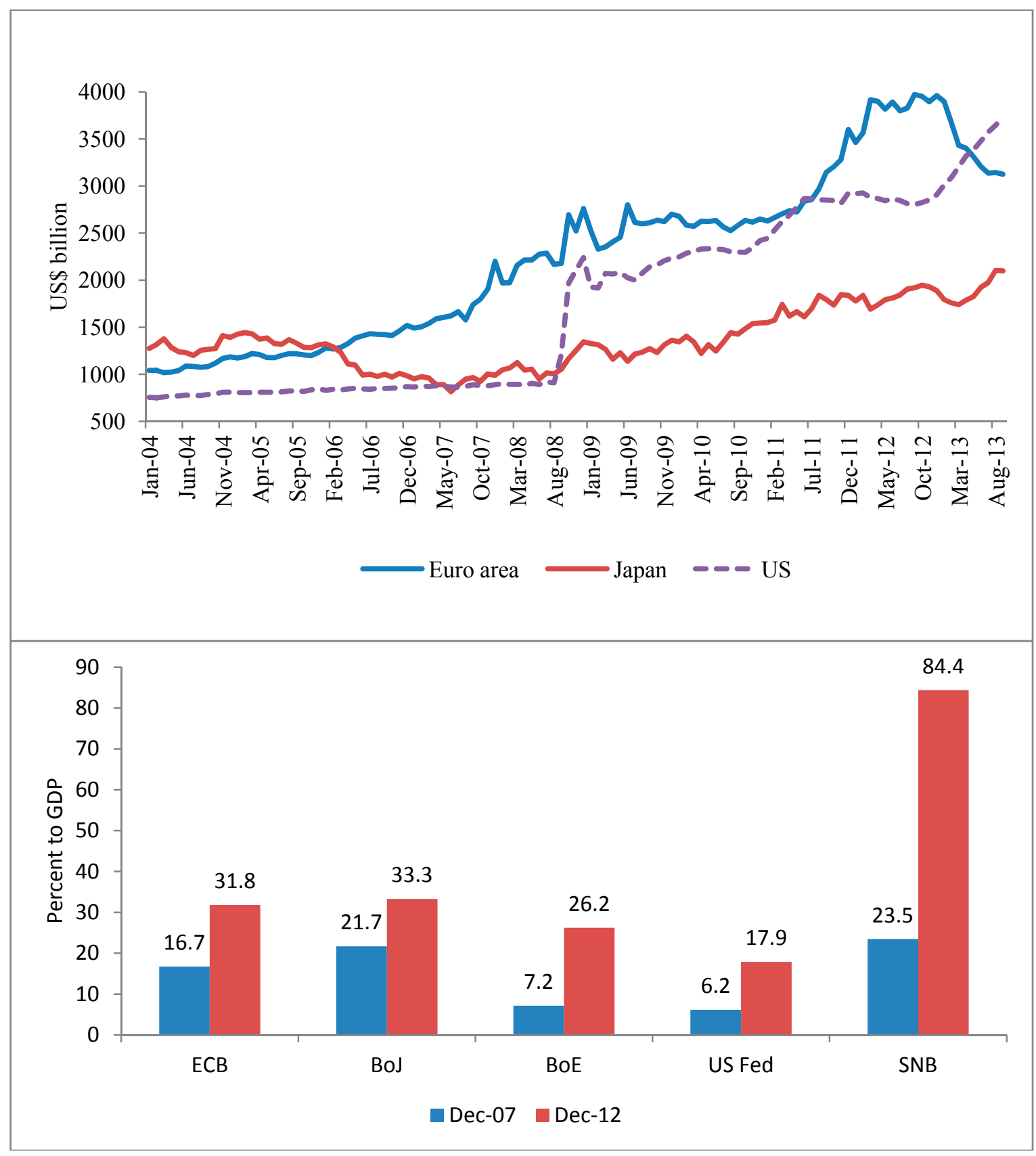

Source: Haver Analytics. 


\section{Monetary Policy in the AdVanced Economies: Spillovers to The EMEs}

\section{Volatile Capital Flows and Exchange Rates: Risks to Financial Stability}

Given the near zero short-term interest rates and also the historically low level of long-term interest rates in the advanced economies, the sharp increase in their balance sheet sizes has encouraged an aggressive search for yield and led to large capital inflows to the EMEs, creating macroeconomic and financial stability challenges. The divergent interest rate cycles in the major reserve-currency advanced economies on the one hand and the EMEs on the other hand have given a strong impetus to capital flows to the EMEs, putting appreciation pressures on the EME currencies. This led to concerns of "currency wars". Capital flows have, however, continued to exhibit their well-known volatility, given the risk-on and riskoff scenario driven by investors' perception of the macroeconomic and financial developments in the source countries rather than the recipient countries (Figures 3-4). For example, the jump in capital flows to the EMEs during 2010 was interrupted by the euro area sovereign debt crisis in 2011. The resumption of capital flows to the EMEs in 2012 was again interrupted in mid-2013 as investors got nervous over the possible tapering by the US Federal Reserve from its UMP. The source of the volatility in capital flows to the EMEs is primarily the monetary developments in the source countries. This is true of not only the recent decades but also historically. Push factors (conditions in international capital markets) perform better than pull factors (conditions in the borrowing countries) in explaining the surge and reversal in capital flows: this was the case during capital flows in Europe and their reversals in the 1920s, akin to the developments in the peripheral Europe in the 2000s (Accominotti and Eichengreen, 2013).

According to IMF (2013b), global factors are found to explain the bulk of changes in bond flows; purchases of Treasury bonds by the Fed have been associated with capital outflows from the United States into EMs (although less so than to non-QE advanced countries); and, reductions in long-term U.S. bond yields and in the VIX (a global index of risk aversion), both known impacts of QE, are significant "push factors" for capital flows. Nonetheless, the IMF (op cit) notes that the share of total inflows attributable to QE or to the push factors is not preponderant and the correlation between capital flows surges and U.S. QE rounds is loose. In contrast, according to the World Bank (2014), global factors (US interest rates, risk and the UMPs) accounted for about 60 percent $^{8}$ of the increase in overall capital inflows to developing countries between 2009 and 2013. Amongst the various categories of capital flows, the World Bank (2014) finds, consistent with previous studies, portfolio flows to be both the most volatile and the most sensitive to external drivers associated with global financial conditions, while FDI investment is relatively insensitive to the effects of global push factors. Within portfolio flows, the flows into developing-country

\footnotetext{
${ }^{8}$ More specifically, US short-term interest rates, the US UMP (mainly QE1 and QE2), the US yield curve and the VIX index explain 4 percent, 13 percent, 20 percent and 26 percent, respectively, of the increase in capital flows between 2009 and 2013. Further analysis by the World Bank indicates complex interactions between the various global factors, especially between the VIX and the monetary conditions in the G-4 (the US, euro area, Japan and the UK).
} 
bond and equity mutual funds are much more sensitive to push factors than the overall portfolio flows. An analysis of financial crises between 1970 and 2011 indicates that these occur in clusters, which suggests that these crises are being caused by common factors or the existence of important contagion effects.

Figure 3: Private Capital Flows to Emerging and Developing Economies

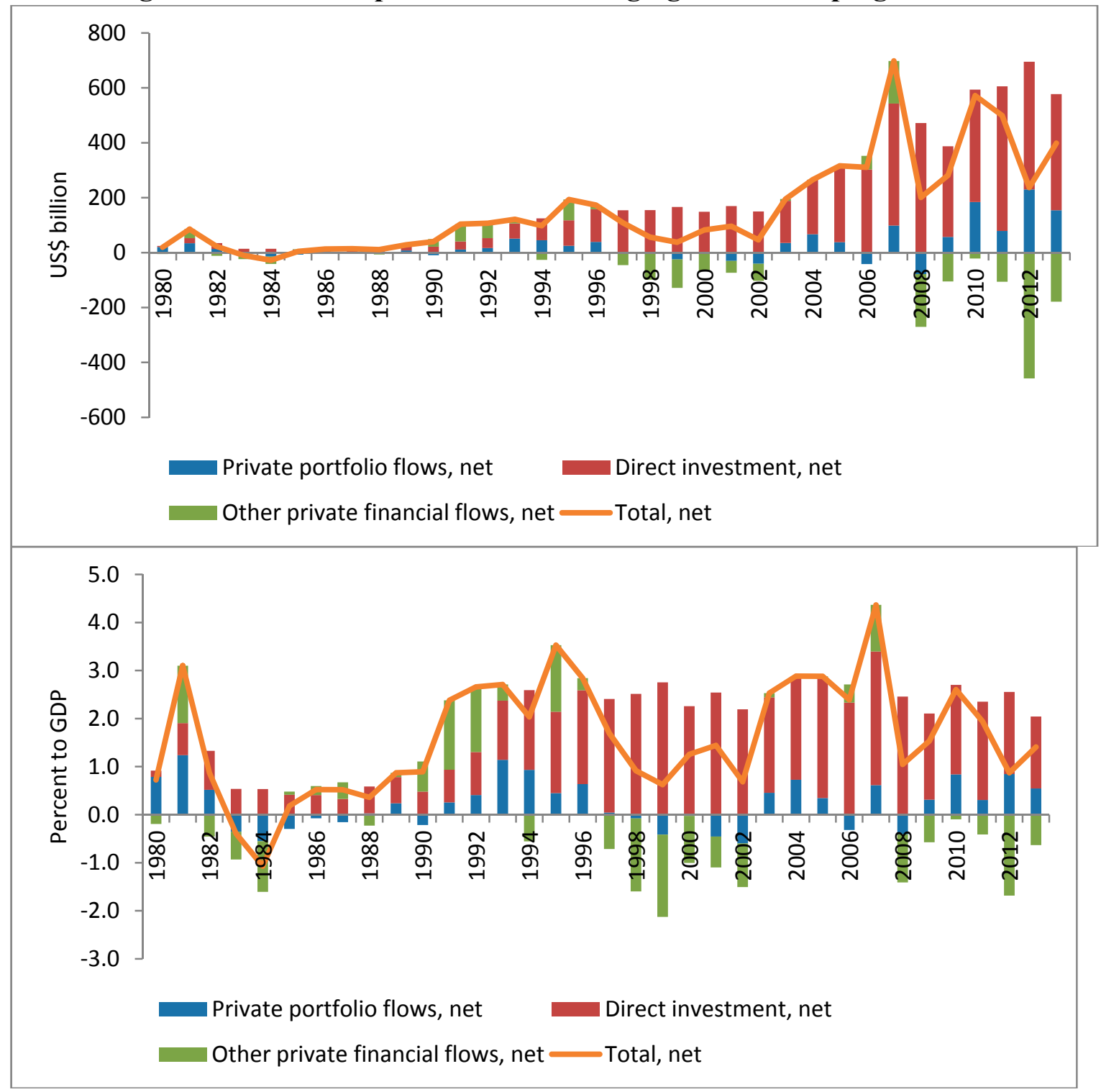

Source: IMF (2013b). 
Figure 4: Monthly Equity and Bond Flows to EMEs

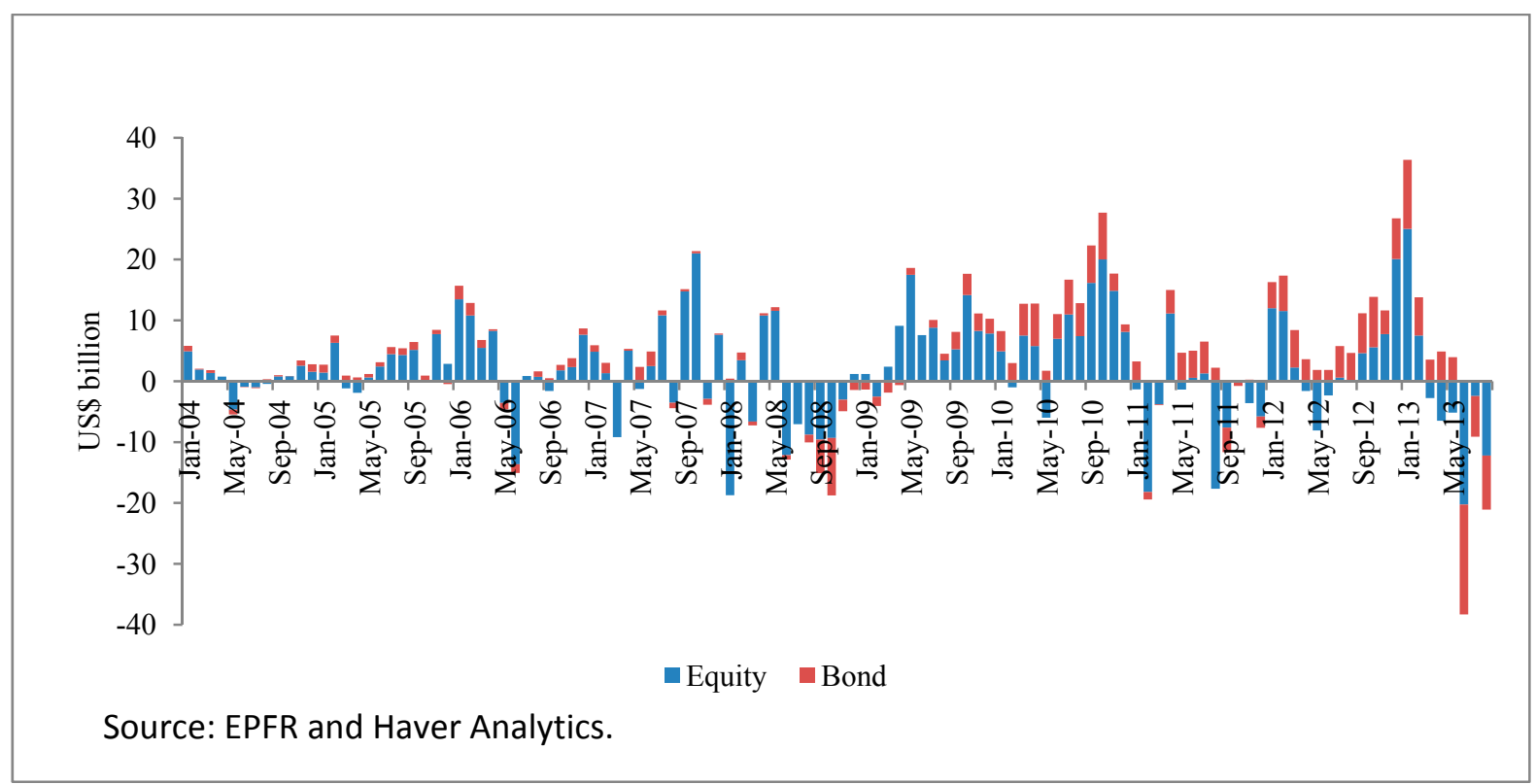

According to Ahmed and Zlate (2013), the sensitivity of capital flows to differentials in the policy interest rates appears to be higher in the post-NAFC period, while growth differentials ceased to be determinant of capital flows in the post-NAFC period. Ahmed and Zlate (op cit) also find that the UMPs seem to have changed the composition of net capital flows to the EMEs towards portfolio flows, although they do not find any statistically significant impact of the UMPs on overall net capital flows. According to Fratzscher, Lo Duca and Straub (2013), the US Fed's QE1 policies triggered a portfolio re-balancing across the EMEs, resulting in capital outflows from the EMEs into the US, which perhaps was the outcome of extreme uncertainty in the global financial markets and the equity capital needs of the US financial institutions in view of their large losses; QE2 policies, on the other hand, led to capital inflows to the EMEs, and vice versa.

UMPs have facilitated capital flows not only to the major EMEs, but also seem to have improved market access to international finance for a wider range of sovereign borrowers. Foreign purchases of portfolio assets (mainly sovereign bonds and equities) in several frontier markets - for example, Ghana, Nigeria, and Zambia - surged in 2012, and, reached new highs in some cases. Sovereign entities in other frontier regions have also accessed international capital markets, either for the first time (Mongolia), or after a prolonged absence from the markets (Bolivia), or in greater size (Serbia) (IMF, 2013d).

Foreign investors hold almost US \$ 1 trillion of EME sovereign debt; half of this amount (US\$ 0.5 trillion) was invested during the 3-year period 2010-12 and the flows during this period were less differentiated against the backdrop of UMPs (Arslanalp and Tsuda, 2014). The US Federal Reserve's prolonged reliance on UMPs has confronted country after country with a difficult choice: to either tolerate a significant exchange rate appreciation - thereby risking competitiveness, jobs and, in some cases, domestic financial 
stability - or follow the Fed in loosening monetary policy (El-Erian, 2014): this dilemma was faced not just by the EMEs, but also by other advanced economies, especially Japan, which experienced a sharp currency appreciation in the context of an already prolonged period of inadequate economic growth.

Overall, the available empirical evidence suggests that the UMPs have led to an increase in the proportion of volatile capital flows (portfolio flows and within these, debt and bond flows) to the EMEs, and thereby increasing their vulnerability to sudden stops, which eventually happened during June-August 2013. More generally, private capital flows are volatile for all countries, advanced or emerging, across all points of time (Bluedorn et al., 2013). Large scale two-way movements in capital flows create sharp adjustments costs. Large inward capital inflows during the initial phase add to nominal and real appreciation of the domestic currency, leading to widening of current account deficits; large capital flows also lead to a boom in credit aggregates and asset prices, and thereby to domestic demand and output, putting further pressure on the current account deficit. Capital flows have contributed to greater corporate leverage and foreign currency exposure in EMEs as well as frontier economies; foreign-currency borrowings by EME corporate have increased by about 50 percent over the past five years (IMF, 2013c). While credit and asset price booms and stronger demand conditions might call for monetary tightening, appreciation of the currency helps to keep inflation low, thereby making it difficult for the central bank to make a case for monetary tightening, especially in the context of inflation targeting frameworks. Monetary tightening is also complicated if higher domestic interest rates attract even higher capital flows, putting further upward pressure on the currency, which then continues to keep inflation low, while continuing to push the current account deficit to more unsustainable levels. These challenges can be daunting for the global economy especially if the leading reserve-currency central bank pursues a highly accommodative monetary policy on a persistent basis.

The empirical evidence indeed indicates that monetary policy in the US has been generally accommodative since the early 2000 s and not just in the post-NAFC period. This then forced other central banks to pursue more-than-desired accommodative monetary policies, resulting in low interest rates globally - the "Great Deviation" (Caruana, 2012b; Gray, 2013; Hofmann and Bogdanova, 2012; Taylor, 2013a). Deviation of the actual monetary policy from the Taylor rule ${ }^{9}$ has been greater in the EMEs (an average of 4 percentage points during 2003-12) than in the advanced economies (an average of 1 percentage point) (BIS, 2013). An assessment of the monetary policy stance based on Taylor rules is best viewed as an illustrative exercise, given that such an exercise involves assumptions about unobservable variables (for example, equilibrium real interest rate, expected inflation and expected output) and there are also issues related to the universality of the policy response coefficients recommended by Taylor for inflation and output (Bernanke, 2010; Hofmann and Bogdanova, 2012). At the same time, an assessment based on Taylor

\footnotetext{
${ }^{9}$ Taylor rule, due to Taylor (1993), is a monetary policy rule which recommends an appropriate policy interest rate taking into account unemployment and inflation conditions in the economy.
} 
rules might be under-estimating the extent of monetary accommodation at the current juncture in view of the UMP, given their explicit objective of and success in lowering longterm interest rates.

During boom periods, exchange rates of high-yielding EMEs continue to exhibit appreciation, contrary to the uncovered interest parity (UIP) theory, but then the subsequent depreciation on the back of retrenchment in capital flows tends to happen fast and in a destabilizing manner (Caruana, 2012a). This pattern was evident during June-August 2013 and January-February 2014 - the most recent episodes of the financial market turmoil - in a number of EMEs (Figure 5). However, unlike the previous such episodes of turmoil, the EMEs were able to manage the challenges relatively well, given their strong fundamentals; nonetheless, their near-term growth prospects have suffered in view of the significant volatility in the financial markets.

The UMP-led exchange rate movements - generally, an appreciation in the EMEs and a depreciation in the advanced economies (Table 1) - have contributed to some rebalancing of global imbalances, especially in the US and China (Table 2). However, no rebalancing has occurred in the large and persistent current account surpluses in Germany and Switzerland. The UMP, combined with the relatively different growth trajectories, has generally led to lower current account surpluses (in the case of surplus EMEs) or higher deficits (in the case of deficit EMEs); this has, therefore, posed challenges to the deficit EMEs. The UMPs of today are the modern version of "currency wars" of the 1920s and the 1930s - a country putting downward pressure on its currency either directly through foreign exchange intervention or indirectly through highly accommodative monetary policies; near zero interest rates are a potential beggar-thy-neighbor policies (McKinnon and Liu, 2013). Although each mature industrial country claims that it is only responding to domestic deflationary pressure and that it is not trying to devalue or conduct a beggar-thy-neighbor policy of direct devaluation, these actions could be characterized as "currency warfare by stealth" because these central banks ignore the impact of their monetary policies on the EMEs. As Rajan (2014b) notes, "some advanced economy central bankers have privately expressed their worry to me that QE “works" primarily by altering exchange rates".

Overall, it is evident that the volatility in monetary policy in the advanced economies is at the root of the volatility in capital flows to the EMEs and the concomitant boom-bust cycle in economic activity and possible financial crises. The conduct and formulation of monetary policy in the advanced economies continues to be dictated by their internal domestic macroeconomic and financial conditions. The FOMC members welcomed the coordinated interest rate cut in October 2008 on the grounds that it would "yield greater economic benefits than unilateral action". If that is the case, the question then arises is: why do we not see more such coordinated actions? Similarly, it would appear that the liquidity swap facilities extended by the US Federal Reserve to other central banks, mostly in the advanced economies, were motivated by the objective of minimizing the adverse impact of US dollar shortage in the global economy on the US and other major advanced economies. It is not apparent that these were motivated by the objective of minimizing the adverse impact on the other economies. 
Figure 5: Exchange Rate Movements

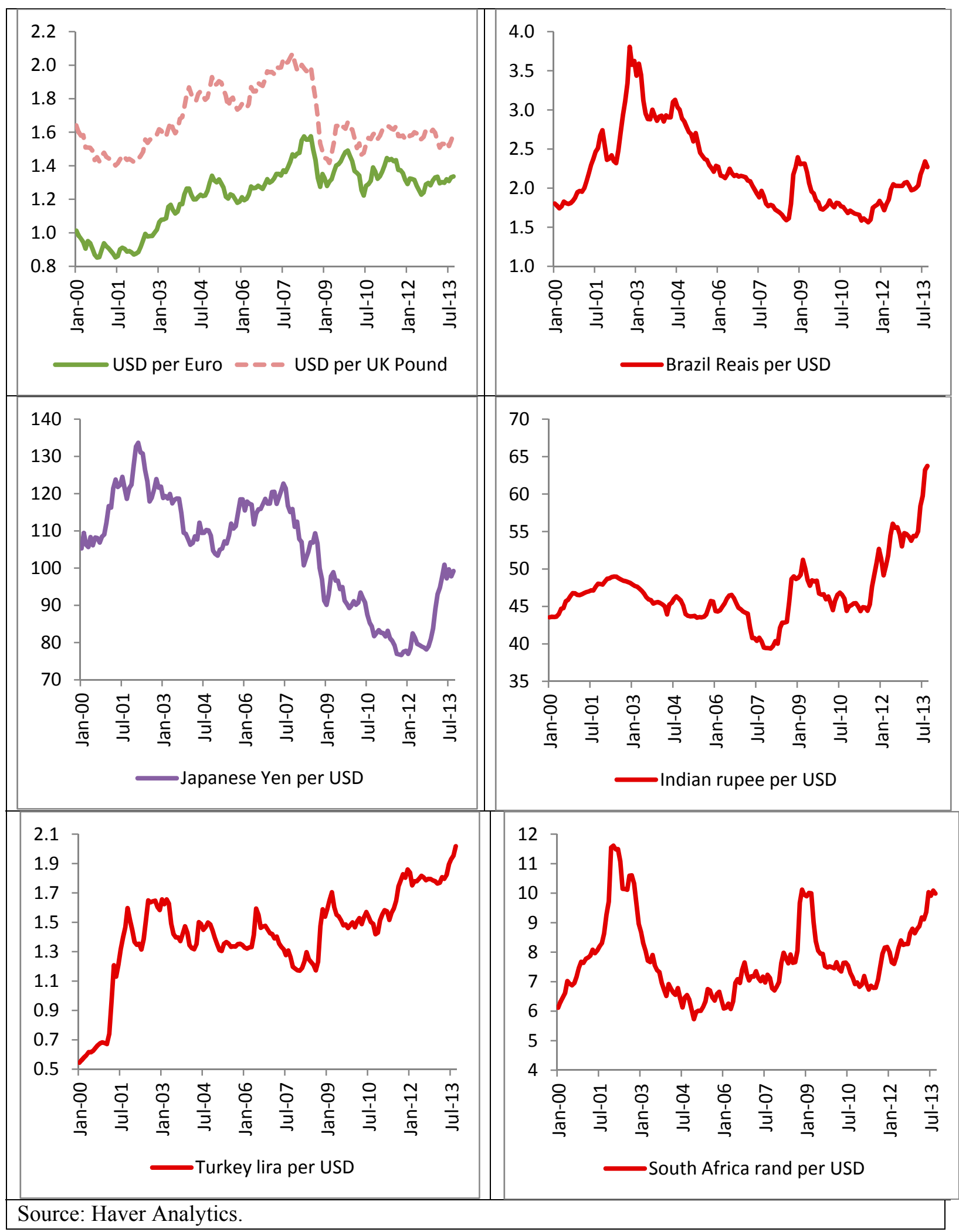

CInternational Monetary Fund. Not for Redistribution 
Table 1: Real Effective Exchange Rate Indices (2007=100)

\begin{tabular}{lrrrrrrr}
\hline Country & $\mathbf{2 0 0 7}$ & $\mathbf{2 0 0 8}$ & $\mathbf{2 0 0 9}$ & $\mathbf{2 0 1 0}$ & $\mathbf{2 0 1 1}$ & $\mathbf{2 0 1 2}$ & $\mathbf{2 0 1 3} \boldsymbol{@}$ \\
\hline Advanced Economies & & & & & & & \\
Australia & 100 & 97 & 94 & 108 & 115 & 117 & 113 \\
Canada & 100 & 97 & 93 & 101 & 103 & 102 & 99 \\
Euro area & 100 & 102 & 102 & 94 & 94 & 89 & 92 \\
Japan & 100 & 107 & 120 & 121 & 123 & 121 & 98 \\
Switzerland & 100 & 104 & 108 & 112 & 123 & 118 & 116 \\
United Kingdom & 100 & 87 & 78 & 79 & 79 & 82 & 81 \\
United States & 100 & 96 & 99 & 95 & 90 & 92 & 93 \\
& & & & & & & \\
Emerging Market Economies & & & & & & & \\
Brazil & 100 & 105 & 105 & 120 & 125 & 113 & 110 \\
China & 100 & 108 & 113 & 112 & 115 & 122 & 130 \\
India & 100 & 95 & 90 & 101 & 100 & 94 & 91 \\
Indonesia & 100 & 95 & 94 & 106 & 106 & 102 & 102 \\
Korea & 100 & 81 & 72 & 77 & 77 & 77 & 80 \\
Malaysia & 100 & 100 & 97 & 102 & 102 & 101 & 102 \\
Mexico & 100 & 97 & 86 & 92 & 92 & 89 & 94 \\
Russia & 100 & 107 & 98 & 107 & 111 & 112 & 115 \\
South Africa & 100 & 87 & 95 & 109 & 107 & 101 & 91 \\
Thailand & 100 & 100 & 97 & 103 & 102 & 102 & 109 \\
Turkey & 100 & 101 & 95 & 104 & 92 & 96 & 96 \\
\hline Source: Bank & & & & & & &
\end{tabular}

Source: Bank for International Settlements.

Note: An increase in the index indicates appreciation and a decline is depreciation.

@: January-September 2013.

\section{Impact of the UMP on EMEs}

The UMPs have been adopted by the advanced economies from their domestic economic objectives and these are, in theory, expected to provide a boost to their economy. Their policymakers also believe that their accommodative monetary policies provide positive spillovers to the rest of the global economy: hence, their UMPs are claimed to be globally beneficial and hence a global public good. For example, Bernanke (2013) notes that UMPs are not 'beggar-thy-neighbor' but rather positive-sum, 'enrich-thy-neighbor' actions, since stronger growth in each economy confers beneficial spillovers to trading partners. Similarly, IMF (2013d, p. 28) proclaims that "generally, what is good for each large, advanced economy is good for the rest of the world (and vice versa)". The empirical evidence on these claims is, however, mixed. 
Table 2: Current Account Balance (Percent to GDP)

\begin{tabular}{lrrr}
\hline Country & $\begin{array}{r}2003-07 \\
\text { (average) }\end{array}$ & $\begin{array}{r}2008-12 \\
\text { (average) }\end{array}$ & Change \\
\hline
\end{tabular}

Emerging Market Economies

\begin{tabular}{lrrr} 
Argentina & 3.3 & 0.8 & -2.6 \\
Brazil & 1.1 & -2.0 & -3.1 \\
China & 6.1 & 4.5 & -1.7 \\
India & -0.3 & -3.3 & -3.0 \\
Indonesia & 2.0 & 0.0 & -2.0 \\
Korea & 2.5 & 2.7 & 0.1 \\
Malaysia & 13.9 & 12.2 & -1.7 \\
Mexico & -1.0 & -1.0 & 0.0 \\
Russia & 8.8 & 4.7 & -4.1 \\
Saudi Arabia & 21.8 & 18.0 & -3.8 \\
South Africa & -4.0 & -4.7 & -0.8 \\
Thailand & 1.6 & 2.8 & 1.2 \\
Turkey & -4.5 & -5.9 & -1.4 \\
& & & \\
Advanced Economies & & & \\
Australia & -5.7 & -3.5 & 2.2 \\
Canada & 1.5 & -2.5 & -4.0 \\
France & -0.2 & -1.7 & -1.5 \\
Germany & 5.1 & 6.3 & 1.2 \\
Italy & -1.0 & -2.4 & -1.5 \\
Japan & 3.9 & 2.6 & -1.3 \\
United Kingdom & -2.1 & -2.1 & 0.0 \\
United States & -5.2 & -3.2 & 2.0 \\
\hline Memo: & & & \\
Advanced economies & -0.9 & -0.3 & 0.6 \\
Euro area & 0.6 & 0.5 & -0.1 \\
Emerging market and & & & \\
developing economies & 3.3 & 1.9 & -1.4 \\
\hline Source: IMF (2013c) & & &
\end{tabular}

Source: IMF (2013c).

According to the IMF (2013d), non-UMP countries, including many EMEs, benefited from UMP early on. Although the subsequent benefits and costs, especially to financial stability, are more difficult to ascertain, the UMP is assessed to have been beneficial, on net, both for the UMP countries and on a global basis. 
Although the UMP has led to buoyant financial markets, its impact on the real economy remains debatable. As IMF (2013d) notes, while the UMPs have boosted growth and prevented deflation, these effects are difficult to measure. For example, according to research summarized in IMF (2013d), UMPs increased domestic GDP growth by about 2 percentage points in the US and the UK, but the estimates lie in a wide range $(0.1$ percentage point to 8 percentage points). While there is a broader agreement that the QE1 policies had some positive impact on economic activity, there is skepticism about the subsequent rounds of UMP (Rajan, 2013). Persistence of UMP announcements on long-term bond yields is critical for the efficacy of the UMP. According to Thornton (2013 and 2014), however, nearly all of the 11 UMP announcement effects were completely offset within 1-2 months of the announcement, suggesting a short-lived effect of UMP and hence it did not increase output and employment in the US. Similarly, Wright (2012) finds that the effects of the UMP on long-term bond yields die off fairly fast. According to Wen (2013), the UMPs cannot effectively boost domestic output and employment unless private asset purchases are highly persistent and extremely large. According to his model, the impact on US output would essentially be zero for asset purchases by the US Fed up to 50 percent of GDP. With total asset purchases by the US Fed being US \$ 4.2 trillion as of March 2014, around 24 percent of GDP, Wen's model would suggest no impact on output of the UMP so far. Overall, it would appear that the UMPs undertaken by the AEs have had limited beneficial effects on the recovery of their own real economies, although these actions did save the AEs from depression in 2008-09 (Mohan 2013).

Moving to the impact of the UMPs on the EMEs, simulations of the Federal Reserve Board's econometric models show that the negative impact of the UMP in the advanced economies on the EMEs from their currency appreciations is roughly offset by the positive effects of stronger demand in the advanced economies (Bernanke, 2013). On the other hand, Taylor (2013b), drawing upon the IMF staff model in Carabenciov and others (2013), argues that lower interest rates in the US, while having the expected positive impact on the US output, have a negative impact on output in the Latin American and the Asian EMEs. The adverse impact on the EMEs is the outcome of the exchange rate channel (negative impact) being stronger than the direct output channel (positive impact). A similar pattern of overall negative cross-border spillover was seen during the 1930s, when interest rates had approached zero and national monetary policies were views as beggar-thy-neighbor policies: during this 1930 s episode, as now, the negative spillover impact from the exchange rate channel offset the direct output impact (Eichengreen, 2013a).

The studies reviewed above focus on cross-border transmission through the simple macroeconomic impact of currency appreciation, but persistently low interest rates in the advanced economies mean that the transmission to the EMEs also takes place through excessive foreign borrowing (whether in local currency or foreign currency), which then threatens financial stability and growth in the EMEs. This scenario was played out during June-August 2013 on US tapering concerns, with large portfolio debt outflows from major EMEs. A new development in recent years in the EMEs is the opening up of local currency bond markets to foreign portfolio investors from the AEs. Turner (2014) argues that this development has major implications for the transmission of AE monetary policy for both 
monetary policy and financial stability in the EMEs. The UMP induced low long-term interest rates have led to corresponding low long-term interest rates in EMEs; and, the withdrawal of UMP will then have reverse corresponding effects on EME interest rates. It has, therefore, become more difficult for EMEs to practice independent monetary policy without significant capital account management. The studies that assess the costs and benefits of the UMP on the EME need to factor all these channels. Moreover, accommodative monetary policies in the advanced economies also boost global oil and other commodity prices, which then have an additional adverse impact on the commodity importing EMEs.

During the June -August 2013 episode of volatility originating in the global financial markets, contrary to conventional wisdom, better fundamentals did not provide insulation to the EMEs from external volatility (Eichengreen and Gupta, 2013): EMEs that allowed their real exchange rates to appreciate and current account deficits to widen during the UMP period were the worst impacted. The best predictor of a sudden stop in capital flows is the preceding capital flows boom and the probability of a sudden stop increases considerably with the length of the preceding boom. Worsening domestic macroeconomic fundamentals are not the ultimate cause of a sudden stop, but are rather the outcome of the preceding capital flows boom (Agosin and Huatia, 2012; Accominotti and Eichengreen, 2013). Overall, macroeconomic management in the EMEs has been rendered more complex through the effects of volatile capital flows and their consequent effects on exchange rate movements, and local currency bond yields.

\section{INTERNATIONAL MONETARY COORDINATION: SCOPE AND FEASIBILITY}

The conventional wisdom is that gains from international monetary policy coordination are small: the central bank's choice of a policy rule has relatively little impact on output and price stability in other economies (Taylor, 2013b). In this view, therefore, if the leading central banks were to adopt rules-based monetary policies similar to the 1980s and 1990s, then there may be no spillovers and hence less of a case for international coordination. However, even if the reserve-currency central banks follow rules-based policies, there may still be spillovers to the EMEs. Rule-based policies in the major advanced economies will inevitably lead to changes in their monetary policies in response to domestic macroeconomic and financial shocks, which will then induce spillovers to the other economies through movements in capital flows, exchange rates, commodity prices and other asset prices. Moreover, the conventional channel stressed by Taylor (2013b) focuses on output and price stability assuming a linear and smooth adjustment in exchange rates and other asset prices, while the concern of the EME authorities also stems from non-linear and abrupt adjustments leading to the risk of overshooting in the asset prices on either side, which then poses financial stability challenges.

Given the pace of globalization and the recurrent financial crises, it is surprising that modern international monetary theory still concludes that the gains from international coordination are negligible or may be even counterproductive. A limitation of this work is that the gains from coordination are analyzed within the macroeconomic realm; monetary 
policies do not spill over into other domains, like trade policy, in these models. Policy coordination can yield welfare gains if international financial markets are incomplete, if policymakers have imperfect information, and if domestic shocks are not perfectly correlated across countries (Frieden and Broz, 2013).

As noted earlier, accommodative monetary policy in the US - the world's largest economy - has induced easy monetary policy globally. If the central banks had taken an international perspective, they would all have been better off by raising rates, thereby setting global average rates more appropriately (Caruana, 2012a). Given the spillovers, there might be a case for the central banks in the advanced economies to internalize these spillovers in their monetary policies. For example, Eichengreen and others (2011) propose an International Monetary Policy Committee, composed of representatives of major central banks, that will report regularly to world leaders on the aggregate consequences of individual central bank policies. The question is: whether this arrangement will be effective? As Eichengreen and others (op cit) themselves note, central bankers might (a) insist that they have no control over another, and (b) that these issues are already discussed informally at the G-20, the BIS and other meetings; nonetheless, these authors are hopeful that the proposed institutional arrangement will be effective as the need to issue periodic public reports can help central bankers identify and publicly air the inconsistencies in their policies. The efficacy of such a public reporting by a group of central banks itself is arguable (Caruana, 2012a). If the leading central banks in advanced economies were to recognize that there are significant spillovers of their policies, they would perhaps not pursue such policies in the first place. The case for international monetary coordination presupposes that a suitable constellation of identifiable and measurable externalities exists and then problems related to incomplete/asymmetric information across countries can be overcome (IMF, 2013d). The key issue in this context is: do the source country central banks recognize that their interest rate and QE policies have spillovers for the EMEs or not? For example, it is interesting to note that the then Fed Chairman Bernanke was skeptical of the role of interest rates in inducing capital flows to the EMEs:

"It is true that interest rate differentials associated with differences in national monetary policies can promote cross-border capital flows as investors seek higher returns. But my reading of recent research makes me skeptical that these policy differences are the dominant force behind capital flows to emerging market economies; differences in growth prospects across countries and swings in investor risk sentiment seem to have played a larger role" (Bernanke, 2013).

Charlie Bean, Deputy Governor of the Bank of England, while being sympathetic to the difficulties that the EMEs face in absorbing large inflows of relatively short-term capital in a safe fashion, is however doubtful about the viability of the proposal to form a committee of central bankers to internalize the spillovers as we do not "know nearly enough about the magnitude - or even the sign - of these spillovers" (Bean, 2013). IMF (2013d) is also agnostic on this aspect. Given the assessment by the leading source country central banks on the spillovers - either there are no spillovers or their impact is indeterminate - the proposed 
International Monetary Policy Committee by Eichengreen and others (2011) is unlikely to provide an effective way forward for coordination. However, while a committee comprised of central banks might have a limited role to play, international organizations like the BIS and the IMF have a key role through enhanced surveillance and studies as impartial surveyors of the global economy. The Fund analysis can help oil the wheels of economic cooperation and coordination by illuminating potential gains from coordinated action through independent and rigorous analysis of spillovers through ruthless truth-telling in a neutral manner and by providing a forum for discussion of mutually advantageous international policy options (IMF, 2013d; Ostry and Ghosh, 2013). The view that IMF surveillance is objective and there is ruthless truth-telling is, however, not borne out by the past experience, especially in the run up to the NAFC (for example, IMF, 2011a). As Ostry and Ghosh (2013) note, neutrality and credibility of the assessor is likely to be undercut when its assessments give rise to suspicion of bias. For the Fund to be an effective neutral assessor, issues related to its governance assume importance. Quotas of countries need to reflect their economic weights appropriately, but progress on this front is slow and halting.

While the preceding analysis focuses on the weight that the Federal Reserve puts on outward spillovers from its monetary policy, a related issue is whether it takes into account the international variables in the conduct and formulation of its monetary policy. Here, the Fed has adopted a policy of benign neglect of the international dimension since the 1970s, even as it had paid significant attention to these aspects in the first two decades of its existence (the 1920s and 1930s) and the 1960s (Eichengreen, 2013b). With the collapse of the Bretton Woods system in 1973, the US was no longer required to defend the exchange rate peg or the statutory gold price, which de-emphasized the need to factor external conditions. Thus, it would appear that even as the US economy has become more integrated with the global economy and is the world's largest economy, the conduct of its monetary policy is turning out to be more insular. Going forward, as the US economy becomes more open and the rest of the world grows larger, international considerations will impinge more directly on the objectives of price and economic stability and the Fed will have to incorporate those considerations more prominently into its policy decisions (Eichengreen, 2013b).

To summarize, the EMEs and a number of observers have stressed the adverse impact of spillovers from the monetary policies of the reserve currency countries; there are proposals for the reserve currency central banks to factor such spillovers in the conduct and the formulation of their monetary policies. However, the leading reserve currency central banks are of the view that their monetary policies do not have negative spillovers for the EMEs or are agnostic about such spillovers. Rather, they believe that their policies are net positive for the EMEs, although the empirical evidence for this proposition is ambiguous. Given this disconnect between the perception of the EMEs and the advanced economies on the spillovers, it is apparent that the EME authorities would be better served by pursuing policies that minimize the spillovers for them, an issue that we take up in the next section. 


\section{MANAGEMent OF SPILlovers by THE EMES}

\section{Capital Account Management}

Since the conduct and formulation of monetary policy in the advanced economies continues to be dictated by their internal domestic macroeconomic and financial conditions, the EMEs would be well-advised to continue with their prudent approach to macroeconomic management. Given that key channels for spillovers are through cross-border capital flows and exchange rate movements, the EMEs would benefit from management of capital flows, and management of exchange rate volatility.

While capital flows, in theory, can add to an economy's investment and growth, the empirical evidence is typically unable to make any case for open capital account (Committee on the Global Financial System (CGFS), 2009; IMF, 2012a; Mohan, Patra and Kapur, 2013). Gains from capital flows have proved elusive in calibrated models as well as in empirical evidence (Rey, 2013). Empirical studies that make the case for benefits from capital account openness often take recourse to indirect benefits - better financial sector development, institutions, governance and macroeconomic stability. But this raises the issue of causality: is it the opening up of the capital account that leads to indirect benefits or is it the gradual development of the domestic financial markets that allows the benefits of subsequent opening up of the capital account to be reaped (CGFS, 2009)? EMEs with greater restrictions on capital inflows (especially on debt liabilities) fared better during the NAFC, and those with higher economy-wide capital inflow restrictions in pre-crisis years experienced smaller growth declines (Ostry et al., 2010, 2011). As noted earlier, cross-country evidence indicates that episodes of boom in capital flows are often an indication of future crisis (Agosin and Huatia, 2012; Accominotti and Eichengreen, 2013). Developing countries have been repeatedly hit hard by swings in global financial markets and there are deeper problems with the excessive financialization of the global economy that has occurred since the 1990s (Rodrik, 2014).

Overall, there is strikingly little convincing documentation of a direct positive impact of financial opening on the economic welfare levels or growth rates of developing countries (Obstfeld, 2009). Available evidence is strongly in favor of a calibrated and well-sequenced approach to the opening of the capital account and its active management by authorities, along with complementary reforms in other sectors and taking into account country-specific features (CGFS, 2009; Obstfeld, 2009). A new strand of the literature on the welfare theory of capital controls argues that under certain circumstances, full capital mobility may not be desirable (Korinek, 2011). As a result of the increased financial globalization, exchange rate flexibility no longer provides the way out of the impossible trinity or from foreign interest rate disturbances (McKinnon, 2012; Rey, 2013). Capital controls are desirable even when the exchange rate is flexible; optimal capital controls - temporary subsidies on capital inflows/taxes on capital outflows during a sudden stop and vice versa during a surge - lean

against the wind and help smooth out capital flow driven business cycles (Farhi and Werning, 2013). 
Drawing on select country experiences, the IMF has proposed a framework for its advice on the spectrum of policy measures available to manage and liberalize inflows, and manage outflows (IMF, 2012). The IMF recognizes the benefits as well as the risks associated with capital flows, and sees some role for capital controls, but stresses these should be temporary and a secondary recourse ${ }^{10}$. It is noteworthy that while the IMF suggests temporary controls to EDEs and that too as a secondary recourse, it endorses highly accommodative monetary policies in the advanced economies for an extended period. Multilateral institutions treat sustained currency intervention by the EMEs with great opprobrium while giving UMPs in the AEs a clean chit (Rajan, 2014b). The IMF's framework also does not examine which types of monetary and regulatory policies trigger the most risky capital flows to the EMEs and what should be the responsibilities of the AEs in such cases (Gallagher and Ocampo, 2013).

It also needs to be recognized that the fast-growing EDEs have higher growth and inflation rates and, hence higher interest rates, than those in the advanced economies. Moreover, their demographic profiles and the relatively low income levels suggest that the growth, inflation and interest rate differentials between the EDEs and the advanced economies can be expected to persist for many years to come (Mohan, 2004; 2009). In the absence of any controls on debt flows, these persistent interest rate differentials run the risk of the EDEs attracting large debt flows for extended periods of time, leading to significant real exchange rate appreciation and booms in credit and monetary aggregates and asset prices. Such developments can then be disruptive and result in severe crises down the line. The interest rate differentials thus reflect structural factors. While cyclical factors can widen or narrow the gap over the cycle, the structural gap is likely to remain. Accordingly, capital account management measures, especially on debt flows, may have to be long lasting, at least while the growth, inflation and interest rate differentials remain. Therefore, the notion that capital account management measures should be temporary, or a last recourse, is flawed. Moreover, the conventional policy recommendation to tighten fiscal policy in response to capital inflows can be sub-optimal. Apart from the legislative and other lags, the fiscal response to manage capital flows has strong distributive effects: a tighter fiscal policy may imply cutting social public spending to give space to capital flows that benefit richer sections of society. A tighter fiscal policy may also force curtailment of public investment, with adverse implications for long-term growth (Gallagher and Ocampo, 2013).

The conventional wisdom regarding capital account management measures is that these measures are not effective. A number of studies (for example, Fratzscher, Lo Duca and Straub, 2013) that examine the efficacy of these measures typically rely on the popular indices of capital controls such as the Chinn-Ito index and the Quinn index, which suffer

\footnotetext{
${ }^{10}$ For example, IMF (2012, para 23) notes that "The temporary re-imposition of CFMs under certain circumstances is consistent with an overall strategy of capital flow liberalization. .... in most circumstances such use of CFMs should be limited and temporary". Similarly, para 33 notes: "While the choice of which CFM to use would depend on the expected effectiveness and efficiency, the design and implementation of CFMs should be transparent, targeted, temporary, and preferably non-discriminatory".
} 
from serious conceptual flaws. First, these indices are often unchanged for years - in fact, for decades - for major EMEs (Mohan, 2011). For example, for India, the Chinn-Ito index is unchanged since 1970, and the Quinn index is unchanged since 1994, even as India has significantly liberalized its capital account since the early 1990s. It is evident that studies which rely on such indicators to measure the efficacy of capital controls will reach misleading conclusions. Second, these indices are based on annual data, whereas the country authorities often fine-tune capital account measures over the course of the year, and hence the studies would miss this nuanced approach. Third, some leakages in controls do not mean that they are not effective. Fourth, the costs of capital account management measures for individual corporations need to be weighed against the macro-benefits for the overall economy that flow from macroeconomic and financial stability. Controls on capital inflows aimed at enhancing financial stability by preventing build-up of currency or maturity mismatches or limiting the growth of intermediation through the domestic banking sector have a useful role (Eichengreen and others, 2011).

\section{Regional Financing Arrangements}

In the aftermath of the US tapering concerns, the EMEs had to manage the large volatility in the financial markets during June-August 2013 through the use of their foreign exchange reserves in the absence of any swap facilities from the reserve currency central banks. Such swap facilities, if available, would have minimized the upheaval that was witnessed during this period. The IMF precautionary liquidity facilities - another short-term liquidity tool available - are still viewed with caution by many EMEs, given the stigma associated with them (IMF, 2014). The stigma with these precautionary instruments is not due to these instruments per se, but is widely perceived to be with the institution itself. Moreover, given the ambiguity, subjectivity and judgment about the criteria associated with the precautionary facilities, it is not clear as to whether how many EMEs are eligible for the precautionary facilities and this haziness might be discouraging the EMEs from approaching the Fund. Finally, the Fund's forward commitment capacity (FCC) was around SDR 270 billion (as of end-2013). It is not clear if this level of FCC is capable of meeting the requirements of large EMEs. For example, the Mexican FCL is around SDR 47 billion and the needs of larger EMEs can be expected to larger. We may also note that the Fund's FCC is, at present, largely dependent on its borrowed resources rather than quota.

Thus, given the stigma with the IMF facilities and the lack of swap facilities from the central banks in the advanced economies, the EMEs have relied on their own instruments and policies to manage the turmoil. These have included exchange rate flexibility, interventions in the foreign exchange market, capital account management measures and domestic monetary and liquidity actions. Notwithstanding the large foreign exchange reserves, the exchange rates depreciated sharply and suddenly in a rather disorderly manner in many EMEs, although these have recovered since September 2013 from their lows. Here, it is 
relevant to note that the IMF, based on its Reserve Adequacy Metric ${ }^{11}$, had maintained that the foreign exchange reserves of the major EMEs are more than adequate, but the markets seem to have questioned this judgment.

Given the developments in the global financial markets since 2008, the limited resources with the IMF, the stalled progress on the IMF's quota and governance reforms, and the near exclusion of the EMEs from the advanced economy central bank swaps, there is a growing interest in the EMEs towards regional financing arrangements (RFAs) (IMF, 2013a). The Asian financial crisis of 1997-98 had led to the creation of the Chiang Mai Initiative (now called the Chiang Mai Initiative Multilateralization with a size of US\$ 240 billion), although the Fund has not been used yet. The RFAs - the European Financial Stability Facility (EFSF)/the European Stability Mechanism (ESM) with a combined lending capacity of Euro 700 billion) - have played an important role in the recent euro area sovereign debt crises, and the IMF turned out to be a small player in the financing arrangements in the region. More recently, the BRICS have proposed a currency arrangement for US \$ 100 billion and work is underway to set up this arrangement. Bilateral currency swaps have also been set up/scaled up in the recent period.

The RFAs appear to provide an additional instrument to the EMEs to manage the volatility in international monetary conditions in the absence of any coordination by the central banks in the advanced economies on the one hand and the absence of any swap facilities from the major AE central banks to the major EMEs. However, the efficacy of the RFAs remains to be tested. The RFAs, in many cases, are tied to IMF arrangements above certain thresholds. Another issue is: whether bilateral or regional currency swaps, that we are seeing now, are an efficient or optimal alternative to the multilateral systems such as the IMF?

\section{Conclusions}

The advanced economies have pursued aggressive unconventional monetary policies since 2008 to provide support to their economies. These policies have taken interest rates, both short- and long-term, in these economies to record low levels and have encouraged large capital outflows, but with recurrent volatility, to the EMEs. The uptrend in capital flows received by the EMEs since 2008 has been interspersed with sudden retrenchments as occurred in 2010-11 on the back of the euro area sovereign debt crisis and in mid-2013 on the back of tapering concerns over the US Federal Reserve's monetary policy stance. These sudden swings in capital flows, as in the previous episodes, have complicated macroeconomic management in the EMEs. While the authorities in the advanced economies argue that the UMPs are net positive not only for them but for the EMEs as well, the empirical evidence casts doubts on these claims.

\footnotetext{
${ }^{11}$ The Reserve Adequacy Metric is a metric developed by the Fund to assess the foreign exchange reserves requirements of the emerging markets and the low income countries and the adequacy of their existing holdings of reserves (IMF, 2011b).
} 
Against this backdrop, this paper looked at the scope and feasibility for central banks in the major advanced economies to internalize the spillovers of their policies. This issue has assumed increased importance in recent months as the unwinding of UMP has begun in the United States: this process can be expected to last for months and possibly a couple of years. The volatility experienced by financial markets in EMEs in mid-2013 and early 2014 has already provided indications of what may happen as the unwinding proceeds, as it must. The issue at hand is whether international monetary coordination can help in reducing the impact of monetary policy normalization in the US, and later in other advanced economies, or if EME authorities will have to manage these spillovers on their own, with corresponding unilateral unconventional policy actions.

If international monetary coordination is to take place, the major advanced economies have to first recognize that their monetary policy actions, especially of the unconventional variety, do have significant spillovers on EMEs and hence have to be internalized. Their current stance, however, is that either there are no significant cross-border spillovers, or they are indeterminate, or that they are in fact overall positive for EMEs. Moreover, there is also a view that monetary authorities' mandates are such that they can only take account of domestic impacts of their policies: taking a cross- border global view would then be beyond their mandates.

If this view does not change, EME authorities would have to manage these spillovers on their own. This would involve a combination of various policies to promote financial stability in their economies: judicious capital account management to reduce the domestic impact of volatile capital flows would have to be a significant element in such policies. There is now near unanimity on the desirability of maintaining flexible exchange rates, but this is tempered by the desire to contain volatility in the face of significant disturbances in global financial markets. Thus, capital account management would need to be accompanied by appropriate foreign exchange intervention, while maintaining exchange rate flexibility, and build up of adequate precautionary foreign exchange reserves. Such macro-management would only be effective in the presence of prudent monetary and fiscal policies, and the continued development of domestic financial markets along with active financial regulation.

Given the expectation of significant volatility resulting from the unwinding of UMP in advanced economies, it is only such active policy making on the part of EMEs which would enable them to meet the challenges posed. But the possible effect of such uncoordinated policy action on the part of both advanced economies and EMEs could be potential fragmentation of global financial markets.

What is the alternative to such outcomes? AE central banks need to explicitly acknowledge and appreciate the spillovers resulting from their unconventional monetary policies. It is only if such understanding is reached can there be a search for some form of international monetary coordination. The IMF, in its role, as the guardian of the international monetary system, should perhaps foster such understanding through its analytical work and then initiate discussions on possible forms of international coordination. 
Central banks of the advanced economies have already set up standing mutual swap facilities. Similar arrangements could be explored by the reserve currency central banks with other significant EMEs through the G20 process, with the assistance of the IMF. Risk mitigation measures would have to be found to protect the reserve currency central banks from potential losses that could arise from the extension of such swap facilities involving currencies that are not freely convertible. EME central banks already have large holdings of reserve currency sovereign debt securities: up to an extent, ways could be found for the use of such securities as collateral for risk mitigation. Moreover, there is a proliferating set of mutual swap arrangements between various EME central banks and with some reserve currency central banks. Regional Financing Arrangements (RFA) are also being developed to manage the consequences of volatile capital flows. All such developments point to the need for greater international monetary coordination, rather than the alternative of increasing financial fragmentation on a global scale.

Increasing communication among monetary authorities, and the transparent availability of such liquidity facilities could do much to actually curb volatility in global financial markets and hence in capital flows to EMEs, thus obviating the need for defensive policy actions on the part of EMEs. Although the comfort of the availability of such swap facilities from the reserve currency central banks runs the risk of encouraging an even greater volume of capital flows to EMEs in the boom period, the existence of such swap facilities is overall expected to be positive for the global economy.

\section{REFERENCES}

Accominotti, Olivier and Barry Eichengreen (2013), "The Mother of All Sudden Stops: Capital Flows and Reversals in Europe, 1919-32", Working Paper 19580, National Bureau of Economic Research

Agosin, Manuel and Franklin Huaita (2012), "Overreaction in Capital Flows to Emerging Markets: Booms and Sudden Stops", Journal of International Money and Finance, Vol. 31, pp. 1140-1155.

Ahmed, Shaghil and Andrei Zlate (2013), "Capital Flows to the Emerging Market Economies: A Brave New World?", International Finance Discussion Papers, No. 181, Board of Governors of the Federal Reserve System.

Arslanalp, Serkan and Takahiro Tsuda (2014), "Tracking Global Demand for Emerging Market Sovereign Debt”, Working Paper WP/14/39, International Monetary Fund.

Bank for International Settlements (2013), $83^{\text {rd }}$ Annual Report, June.

Bean, Charlie (2013), "Global Aspects of Unconventional Monetary Policies", Bank of England, August. 
Benes, Jaromir, Michael Kumhof, Douglas Laxton, Dirk Muir, and Susanna Mursula (2013), "The Benefits of International Policy Coordination Revisited", Working Paper WP/13/262, International Monetary Fund.

Bernanke, Ben (2010), "Monetary Policy and the Housing Bubble", Board of Governors of the Federal Reserve System, January.

--- (2013), "Monetary Policy and the Global Economy", Board of Governors of the Federal Reserve System, March.

Blanchard, Olivier, Jonathan Ostry and Atish Ghosh (2013), International Policy Coordination: The Loch Ness Monster", IMF Direct - the IMF Blog, December.

Bluedorn, John, Rupa Duttagupta, Jaime Guajardo and Petia Topalova (2013), "Capital Flows are Fickle: Anytime, Anywhere”, Working Paper WP/13/183, International Monetary Fund.

Board of Governors of the Federal Reserve System (2008a), "Joint Statement by Central Banks" (October 8), available at http://www.federalreserve.gov/newsevents/press/monetary/20081008a.htm

---- (2008b), "Minutes of the Federal Open Market Committee", available at http://www.federalreserve.gov/monetarypolicy/fomcminutes20081029.htm

Buiter, Willem (2014), “The Fed's Bad Manners Risk Offending Foreigners”, Financial Times, February 4.

Carabenciov, Ioan, Charles Freedman, Roberto Garcia-Saltos, Douglas Laxton, Ondra Kamenik, and Petar Manchev (2013), "GPM6 - The Global Projection Model with 6 Regions", Working Paper WP/13/87, International Monetary Fund.

Caruana, Jaime (2012a), "Policymaking in an Interconnected World", Bank for International Settlements, August.

--- (2012b), "International Monetary Policy Interactions: Challenges and Prospects", Bank for International Settlements, November.

Chinn, Menzie and Hiro Ito, 2008, "A New Measure of Financial Openness", Journal of Comparative Policy Analysis, 10 (3) September, 309-322.

Committee on the Global Financial System (2009). Capital Flows and Emerging Market Economies. CGFS Publication No. 33. January. Bank for International Settlements.

Eichengreen, Barry (2011), "International Policy Coordination: The Long View", Working Paper 17665, National Bureau of Economic Research.

--- (2013a), “Currency War or International Policy Coordination?”, Journal of Policy Modeling, Vol. 35(3), pp. 425-433. 
--- (2013b), "Does the Federal Reserve Care About the Rest of the World?", Journal of Economic Perspectives, 27(4), Fall, pp.87-104.

--- (2014), “The Dollar and the Damage Done”, Project Syndicate, February.

Eichengreen, Barry and others (2011). "Rethinking Central Banking." Report of the Committee on International Economic Policy and Reform. Available at http://www.brookings.edu/research/reports/2011/09/ciepr-central-banking.

Eichengreen, Barry and Poonam Gupta (2013), "Tapering Talk: The Impact of Expectations of Reduced Federal Reserve Security Purchases on Emerging Markets".

El-Erian, Mohamed (2014), "The Instability in Central Bank Divergence”, Financial Times, February 26.

Farhi, Emmanuel and Ivan Werning (2013), "Dilemma not Trilemma? Capital Controls and Exchange Rates with Volatile Capital Flows", Paper presented at the 14th Jacques Polak Annual Research Conference hosted by the International Monetary Fund.

Fleming, Michael and Nicholas Klagge (2010), "The Federal Reserve's Foreign Exchange Swap Lines", Current Issues in Economics and Finance, 16(4), pp. 1-7, April, Federal Reserve Bank of New York.

Fratzscher, Marcel, Marco Lo Duca and Roland Straub (2013), "On the International Spillovers of US Quantitative Easing”, Working paper 1557, European Central bank, June.

Frieden, J.A. and J.L. Broz (2013), “The Political Economy of International Monetary Policy Coordination", In Gerard Caprio (ed.), Handbook of Safeguarding Global Financial Stability: Political, Social, Cultural, and Economic Theories and Models, Vol. 2, pp. 81-90. Oxford: Elsevier Inc.

Gallagher, Kevin and Jose Antonio Ocampo (2013), "IMF's New View on Capital Controls", Economic and Political Weekly, Vol. XLVIII (12), pp. 10-13.

Gray, Colin (2013), "Responding to a Monetary Superpower: Investigating the Behavioral Spillovers of U.S. Monetary Policy", Atlantic Economic Journal, Vol. 41, pp. 173-184.

Hofmann, Boris and Bilyana Bogdanova (2012), "Taylor Rules and Monetary Policy: A Global 'Great Deviation'?”, BIS Quarterly Review, Bank for International Settlements, September, pp. 37-49.

International Monetary Fund (2011a), "IMF Performance in the Run-Up to the Financial and Economic Crisis", January, Independent Evaluation Office.

---- (2011b), “Assessing Reserve Adequacy,” February. 
--- (2012). "The Liberalization and Management of Capital Flows: An Institutional View" November.

--- (2013a), Stocktaking the Fund's Engagement with Regional Financing Arrangements, April.

---- (2013b), 2013 Spillover Report, August.

---- (2013c), 2013 Pilot External Sector Report, August.

--- (2013d), Global Impact and Challenges of Unconventional Monetary Policies, September.

--- (2013e). World Economic Outlook Database, October.

--- (2014), "Review of Flexible Credit Line, the Precautionary And Liquidity Line, and the Rapid Financing Instrument, January.

Korinek, A. (2011), "The New Economics of Prudential Capital Controls." IMF Economic Review 59, no. 3: 523-561.

McKinnon, Ronald (2012), "Carry Trades, Interest Differentials, and International Monetary Reform”, Journal of Policy Modeling, Vol. 34(4), pp. 549-567.

McKinnon, Ronald and Zhao Liu (2013), "Modern Currency Wars: The United States versus Japan”, Working Paper 437, Asian Development Bank Institute.

Mohan, Rakesh (2004), "Challenges to Monetary Policy in a Globalizing Context." Reserve Bank of India Bulletin, January.

(2009), Monetary Policy in a Globalized Economy: A Practitioner's View, Oxford University Press, New Delhi.

(2011), Growth with Financial Stability: Central Banking in an Emerging Market, Oxford University Press, New Delhi.

---- (2013), "Global Spillovers and Domestic Monetary Policy: An Emerging Market Perspective", Comments on Menzie Chinn "Global Spillovers and Domestic Monetary Policy: The Impacts on Exchange Rates and other Asset Prices", 12th BIS Annual Conference, Lucerne, Switzerland on June 21, 2013

Mohan, Rakesh, Michael Debabrata Patra and Muneesh Kapur (2013), "The International Monetary System: Where Are We and Where Do We Need to Go?", Working Paper WP/13/224, International Monetary Fund.

Obstfeld, Maurice (2009), "International Finance and Growth in Developing Countries: What Have We Learned?" IMF Staff Papers 56, no. 1: 63-111. 
Ostry, J. D., A. R. Ghosh, K. Habermeier, M. Chamon, M. S. Qureshi and D. B. S. Reinhardt (2010), "Capital Inflows: The Role of Controls", Staff Position Note 10/04, International Monetary Fund.

Ostry, J. D., A. R. Ghosh, K. Habermeier, M. Chamon, M. S. Qureshi, L. Laeven, and A. Kokenyne (2011), "Managing Capital Inflows: What Tools to Use?", Staff Discussion Note 11/06, International Monetary Fund.

Ostry, J. D. and A. R. Ghosh (2013), "Obstacles to International Policy Coordination, and How to Overcome Them?”, Staff Discussion Note 13/11, International Monetary Fund.

Prasad, Eswar (2014), "The Fed is Not to Blame for Turmoil in Emerging Markets", Financial Times, February 12.

Rajan, Raghuram (2013), “A Step in the Dark: Unconventional Monetary Policy after the Crisis”, Andrew Crockett Memorial Lecture, Bank for International Settlements, June.

---- (2014a), "Rajan Warns of Policy Breakdown as Emerging Markets Fall", Bloomberg, January 31, http://www.bloomberg.com/news/print/2014-01-30/rajan-warns-of-globalpolicy-breakdown-as-emerging-markets-slide.html

----- (2014b), “Competitive Monetary Easing: Is It Yesterday Once More?”, Remarks at the Brookings Institution, Washington DC, available at http://rbi.org.in/scripts/BS SpeechesView.aspx?Id=886

Rey, Hélène (2013), "Dilemma not Trilemma: The Global Financial Cycle and Monetary Policy Independence", Paper presented at the Federal Reserve Bank of Kansas City Economic Policy Symposium, Jackson Hole, Wyoming.

Rodrik, Dani (2014), “Death by Finance”, Project Syndicate, February.

Rodrik, Dani and Arvind Subramanian (2014), "Emerging Markets' Victimhood Narrative", Bloomberg, January, http:/www.bloombergview.com/articles/2014-01-31/emergingmarkets-victimhood-narrative

Taylor, John (1993), "Discretion versus Policy Rules in Practice", Carnegie-Rochester Conference Series on Public Policy, Vol. 39, pp. 195-214.

---- (2013a), "International Monetary Coordination and the Great Deviation", Journal of Policy Modeling, Vol. 35, pp. 463-472.

---- (2013b), “International Monetary Policy Coordination: Past, Present and Future”, Paper presented at the 12th BIS Annual Conference, June.

Think Tank 20, The G-20 and Central Banks in the New World of Unconventional Monetary Policy, Kemal Dervis and Homi Kharas, editors, The Brookings Institution, August 2013. 
Thornton, Daniel L. (2013), "An Evaluation of Event-Study Evidence on the Effectiveness of the FOMC's LSAP Program: The Reasonable Person Standard”, Working Paper 2013-033A, Federal Reserve Bank of St. Louis, October.

----- (2014), "Has QE been Effective", Economic Synopses, Number 3, Federal Reserve Bank of St. Louis, February.

Turner, Philip (2014), "The Global Long-term Interest Rate, Financial Shocks and Policy Choices in EMEs", Working Paper 441, Bank for International Settlements.

Wen, Yi (2013), “Evaluating Unconventional Monetary Policies-Why Aren't They More Effective?', Working Paper 2013-028A, Federal Reserve Bank of St. Louis.

Wright, Jonathan (2012), “ What does Monetary Policy do to Long-term Interest Rates at the Zero Lower Bound?”, Economic Journal, Vol. 122, November, pp. F447-466.

World Bank (2014), Global Economic Prospects: Coping with Policy Normalization in Highincome Countries, Vol. 8, January. 